\title{
Complete Gasification under Pressure with Steam and Oxygen
}

\author{
By L. Szeszich
}

(The National Resource Section of G.H.Q.)

SYNOPSIS :-Theoretical considerations indicated and laboratory experiments proved that, if carbon is gasified with steam and oxygen under pressure, not only the oxydes of carbon and hydrogen are formed, but also methane. Therefore the gas has a considerably higher heating value than ordinary water gas. These considerations confirmed by laboratory experiments resulted in the unique process of pressure gasification developed by the "LURGI" in Germany. The first industrial scale plant by this process was built in 1936, the second one in 1940 with the daily production capacity of $465,000 \mathrm{~m}^{3}$ gas and the third one in 1942 with the daily production capacity of $250,000 \mathrm{~m}^{3}$ gas. Brown coal is used as raw material in these plants and the only product of the gasification, beside some tar and light oil, is gas with a heating value * of $3,900 \mathrm{kcal} / \mathrm{m}^{3}$ on the avarage. Full scale tests showed that not only brown coal, but also bituminous coal and even anthracite can be used as raw materials. The process would have a great importance in Japan, it allows the making of a high calorie gas without using caking coal, but from a low grade coal and having only tar and light oil as by-products. Such gas is suitable as utility gas, as industrial heating gas and as starting material for the making of sythesis gas.

\section{ガソリンの構造分析法及びその台湾錦水產 ガソリンへの適用に就て（第 $1,2,3$ 報）}

一一昭和 25 年 6 月 15 日受理一

元台灣総督府天然瓦斯研究所 富 樫 喜 代 治

\footnotetext{
要旨 比パラコールとネクランーの恒数とを併用するガンリンの静造分析諭を述べ，次にこの構 造分析諭を錦水ガンリンに適用して，その各溜分の構造成分を推定した。最後に以上の推定に基 いて $105 \sim 110^{\circ} \mathrm{C}, 120 \sim 125^{\circ} \mathrm{C}$ の 2 溜分の屈折率 $n_{\mathrm{D}}^{20}$ の理論值を算出すると实測值とよく一致 する結果を得た。
}

\section{第 1 報＼cjkstart錦水産ガソリンの物理性の測定に就て}

(I) 緒

言

ガソリンの構造分析に比パラコールを用らる $\mathrm{M}$. Marder の方法は各炭化水素系の比バラコールの差異 少く非実用的な憾がある。從つてその適用にあたり炭 化水素系の正確な分離と測定の精密を要するので，筆 者は此点に留意しその央用性を検討した。而して飽和
炭化水素の構造を推定するには，Marder の方法にて はナフテン系又はパラフィン系炭化水素の何れかの構 造を仮定しなければならない。結局その儘ではパラコ ールを知つてもその構造の闡明に筫せしむる事が出來 ない。本法に於ては Nekrassow の常数を組合わせて 此点を解決せんとするものである。 


\section{（II）実驗}

（1）原試油及び脫芳香族分試油の精溜 試料に供 したのは錦水 32 号井油てあつて, 同油を無水芒确, 金属ナトリウムを用いて十分脫水し，常圧にて〜 173은 Cの溜出油についてウイ1 マーカラムを用い，雷熱式 油浴によつて $135^{\circ} \mathrm{C}$ まて常圧精溜を行つた。精溜 塔は長さ $95 \mathrm{~cm}$ 徑 $26 \mathrm{~cm}$ のウイリマーカラムを二 箇接続してその外側を石綿紐て以て充分に保盜し，溫 度計には刻度 $01^{\circ} \mathrm{C}$ の予め補正したものを用いた。 更に探取日時を異にした昤水 32 号井油につき，芳香 族炭化水素を除去し，之をポ!ヒールニア，ク式精密 高温分溜裝置て $5^{\circ} \mathrm{C}$ 分劃分溜を行つた。原試油は試 料 $5763 \mathrm{~g}$, 眖芳香族油は試料 $2491 \mathrm{~g}$ を用い, 前後 2 回の分溜を行つた。第 1 表はその結果を示するのて ある。

\begin{tabular}{|c|c|c|c|}
\hline \multirow[t]{2}{*}{ 溜 分 } & \multicolumn{2}{|c|}{ 第 1 表 } & $(w \mathrm{wt} \%)$ \\
\hline & $\left({ }^{\circ} \mathrm{C}\right)$ & 原 試 油 & 脫芳香族分伷 \\
\hline (1) & $\sim 60$ & 05 & 03 \\
\hline (2) & $60 \sim 65$ & 08 & 02 \\
\hline (3) & $65 \sim 70$ & 27 & 02 \\
\hline (4) & $70 \sim 75$ & 44 & 03 \\
\hline (5) & $75 \sim 80$ & 07 & 07 \\
\hline (6) & $80 \sim 85$ & 25 & 05 \\
\hline$(7)$ & $85 \sim 90$ & 08 & 20 \\
\hline (8) & $90 \sim 95$ & 19 & 35 \\
\hline (9) & $95 \sim 1 C \theta$ & 59 & 38 \\
\hline (10) & $100 \sim 105$ & 64 & 58 \\
\hline (11) & $105 \sim 110$ & 58 & 113 \\
\hline (12) & $110 \sim 115$ & 49 & 104 \\
\hline (13) & $115 \sim 120$ & 13 & 36 \\
\hline (14) & $120 \sim 125$ & 28 & 138 \\
\hline (15) & $125 \sim 130$ & 74 & 53 \\
\hline (16) & $130 \sim 135$ & 5.4 & 109 \\
\hline \multicolumn{2}{|c|}{ 䇳留物及ひ損失 } & 458 & 274 \\
\hline
\end{tabular}

(2) 原試油の芳香族分除去 $\sim 173^{\circ} \mathrm{C}$ 溜出油の芳 香族分除去にあたり用いた操作は次の通りてある。予 め試料を十分に冷却し之に 25 倍容の硫矿酸（酳酸 25 $\mathrm{wt} \%$ ，硫酸 $58 \mathrm{Wt} \%$ ，水 $17 \mathrm{wt} \%$ ）を加之，10分間水 却した後振温㙨を用いて 30 秒間振湯して再ひ 5 分間 氷却後 30 秒宛振盛し，こうして 12 分間振盈を継続 寸る。次に氷冷し 30 分間靜置後混酸を排除し，新に 91\% 硫酸を初試料の 15 倍容加え，10 分間水冷した 後 30 秒宛 2 分間拆昜与る。そして 1 時間静置後 $10^{\circ} \mathrm{C}$
て測容した。次にアルカリ洗，水冼をなし塩化カルン ウムて以て翰燥して, 比重 $d_{\mathrm{D}}^{20}$ を測定寸る。こうして 更に残油に初試料の 02 倍容の硫硝酸を加之, 同容の 91\% 硫酸を用いて，同样の実驗を反覆し残夜の比重 $d_{\mathrm{D}}^{20}$ か近似值となる迄，又硫确酸による芳香分検出反 応か認められなくなる迄これを繰返す。以上の実驗結 果は第 2 表に示す通りてある。

\section{第 2 表 芳香分除去の実驗結果}

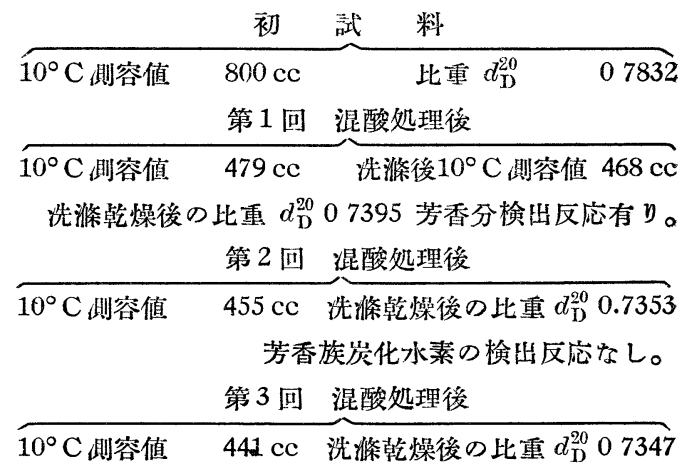

第 2 回昆酸処理後は硫㗂酸による検出反応加陰性な こと，站に比重の近似的な事から，芳香族分は完全に 除去されたと見る事か出來る。これにより本試料中の 芳香族分の含有率を承めれは，417 Vol\% となる。

（3）溜分の諸性狀試驗方法及ひ試驗結果 原試油 の $5^{\circ} \mathrm{C}$ 分劃油につき, その諸性斯郎ち此重, 屈折率, 表面張力及ひ分子量を測定し，次に各分劃油より $80 \%$ 硫酸を用いて予め正確度を確かめて拉いた方法に從つ て不飽和炭化水素を除去し，その残溜分劃油につき同 様の則定を䋁行する。更に芳香族炭化水素を除去した 各分劃油及ひ予め芳香族分を除去した試油の $5^{\circ} \mathrm{C}$ 分 劃油についても，同样に以上の性壯を則定した。

次の項目に就いて夫々記載の要領によつて上記の各 種分離油の性狀を試驗する。

1 比重 Ostwald 比重計を用い, $d_{\mathrm{D}}^{20}$ を測定する。

2. 屈折率 Abbe 屈折計を用い $n_{\mathrm{D}}^{20}$ を則定する。 以上によつて比重, 屈折率を測定した結果を図示すれ は，夫々第 1 図，第 2 図の通りてある。(第 1 及ひ第 2 図参照)

3 表面張力 Sugden の毛細管上昇法によつて則 定する。之に用いた毛細管は可及的均一な孔徑を有す るもの及て内形断面なものを二箅選択し，一定量の水 銀桂を移動させてその孔徑を測定した。こうしてメこ スカスを夫々管端より 20〜41 $1 \mathrm{~mm}, 0 \sim 15 \mathrm{~mm}$ の間 に至らしめて，管徑の不均一による誤差を除去した。 溫度は $20 \pm 002^{\circ} \mathrm{C}$ 以冈にこれを一定に保たせ，読取 


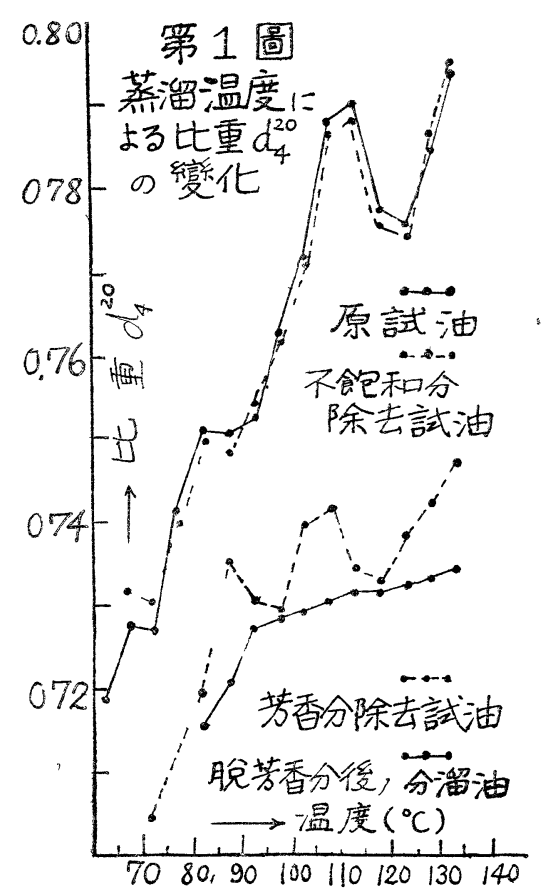

第 3 表 分子量測定結果

溜分原試油芳香分脱芳香族

除去油分溜油

顯微鏡によつて $1 / 100 \mathrm{~mm}$ 迄読取つた。叉測定容器に 少し王を加えた後及ひ少し圧を減した後観測を反復し 前後を通じて誤差 $\pm 0.002 \mathrm{~cm}$ 以內に至らしめた。

4 分子量・蒸留曲線及ひ 比重, 屈折率溫度曲線よ

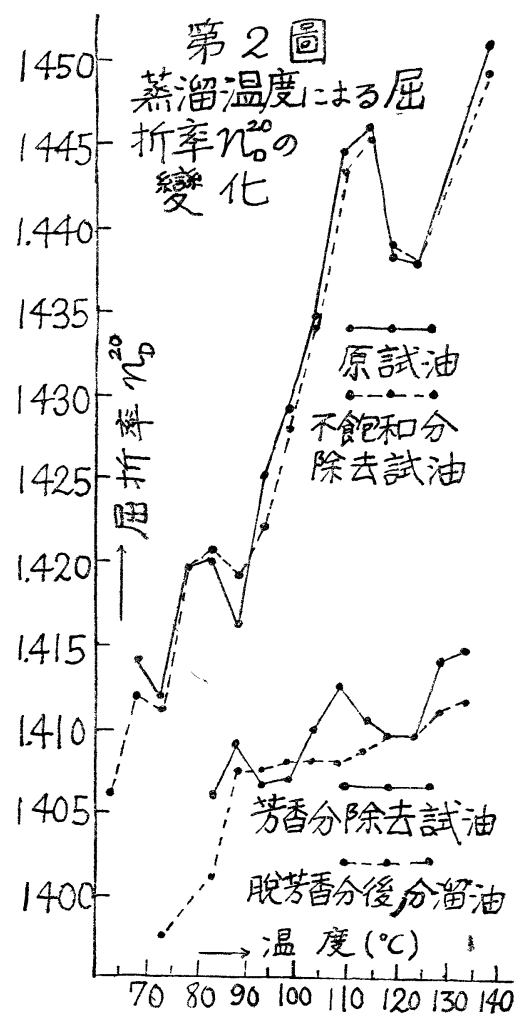

り,ヘンゾールを最も多量に含を溜分は $80 \sim 85^{\circ} \mathrm{C}$ 溜 分と考之られるのて原試油分劃油の $65 \sim 70^{\circ} \mathrm{C}, 70 \sim$ $75^{\circ} \mathrm{C}, 75 \sim 80^{\circ} \mathrm{C}, 80 \sim 85^{\circ} \mathrm{C}, 85 \sim 90^{\circ} \mathrm{C}$ 溜分だけは ニトロヘンゾールを，其他は緿てベンゾールを容媒と して氷点降下法によつて分子量を承める。その結果は 第3表に示す通りてある。

\section{(II) 䋓括}

原試料を分溜し各留分より定量的に不飽和分, 芳香 。族分を除去し夫々梅造分析上必要な諸性妝を則定し た。一方芳香族分除去の初試料よりの溜分についても 同様の測定を行つた。

錦水ガソリンの分溜曲線を作ると，75, 85, 105, 130 ${ }^{\circ} \mathrm{C}$ 附近に著しい四つの極大を認め, 脫芳香族分油の 分溜曲線も 75〜80, 105 110, 120～ $125^{\circ} \mathrm{C}$ の溜分に 最大溜出量を示している事を知る。

蒸溜溫度による比重曲線と屈折率曲線を比較すれ は，互に相似の関係にあり，同曲線上に明らかに数䈯 の極大点かある事を認める。

\section{第 2 報 錦水産ガリリンの各炭化水素分の定量とパラコールに就て}

(I) 不能和炭化水素の定量

原試油の $5^{\circ} \mathrm{C}$ 分劃油について不飽和度を測定する
のに從來の臭素価則定の方法にその锰從えは屡々一致 しない値を得る。これは主として試薬より発生する臭 
素カスの逸散及ひ区応に依つて生する臭化水素酸の生 成に因るものと考元られるのて，測定操作を次の通り に修正した。これによつて同一不飽和物に就いてよく 一致する臭素価を得た。

(a) 加える $\mathrm{KBr}-\mathrm{KBrO}_{3}$ 溶夜は必要量よりも僅 かに過量な事。

（b）加元る KI 溶夜は予め所定量を小試驗管に大 れ，速かに容器に投入する事。

加えた $\mathrm{KI}$ 溶夜は僅少量の沃素を遊離しているのて $\mathrm{Na}_{2} \mathrm{~S}_{2} \mathrm{O}_{3}$ 標隼夜て定量し，これを臭素価則定に要し そ逆商定の $\mathrm{Na}_{2} \mathrm{~S}_{2} \mathrm{O}_{3}$ 溶夜の $\mathrm{cc}$ より减した。こうし て各溜分の臭素価を測定し，平均分子量より不命和炭 化水素の wt\% を求めた。更に不飽和分はこれを二重 結合一简を有する不飽和炭化水素に属するものと見做 し，その比重 $d_{4}^{20}$ と分子量との関係図より該溜分の分 子量に相当する不飽和炭化水素の比重 $d_{4}^{20}$ を氷め, 次 式によつて wt\% を vol\% に転換した。不飽和炭化 水素の $\mathrm{vol} \%=$ 不飽和炭化水素の $\mathrm{wt} \% \times\left(\mathrm{D}_{4}^{20} / d_{4}^{20}\right)$ 但 し $\mathrm{D}_{4}^{20}$ は該溜分の原試油の此重。

\section{第 4 表 不飽和岩化水素分の測定} 溜分臭素価

$$
\begin{array}{rr}
0 \\
001 \\
045 \\
020 \\
018 \\
016 \\
0 \\
032 \\
035 \\
049 \\
013
\end{array}
$$$$
001
$$$$
045
$$$$
020
$$$$
018
$$$$
016
$$$$
0
$$$$
035
$$$$
049
$$

\begin{tabular}{|c|c|}
\hline wt $\%$ & vol\% \\
\hline 0 & 0 \\
\hline 01 & 01 \\
\hline 02 & 02 \\
\hline 01 & 01 \\
\hline 01 & 01 \\
\hline 01 & 0.1 \\
\hline 0 & 0 \\
\hline 02 & 02 \\
\hline 02 & 02 \\
\hline 03 & 03 \\
\hline 01 & 01 \\
\hline 04 & 04 \\
\hline 04 & 04 \\
\hline
\end{tabular}$$
064
$$$$
046
$$

\section{(II) 芳香族炭化水素の定量}

芳香族炭化水素の除去は実驗の性質上最も正確を期 さなけれはならない。之には予め正確度を検討した硫 硝酸法に拠る事とした。本法に依る容積收縮値に芳香 族分を除去したガリリンについて行つた空白試驗によ る禣正値を加之て芳香族炭化水素の 容積百分率とし た。芳香族炭化水素を予め除去した錦水ガソッンにつ いて空白試驗老行弓と硫硝酸 $30 \mathrm{cc}, 91 \%$ 硫酸 $15 \mathrm{cc}$ を用いた時 $099 \%$ ，硫硝酸 $45 \mathrm{cc}, 91 \%$ 硫酸 $25 \mathrm{cc}$ を
用いた時 $165 \%$ の吸收を來すので，芳香族炭化水素 除去の條件に灾じて上記に相当する禣正を施して芳香 族炭化水素の容積百分率とした。芳香族炭化水素除去 の硫酸の試料に対する容積比，91\%硫酸の健用容積， 補正值芳香分含有百分率を一括して示せは第 5 表の通 りてある。

\section{第 5 表 芳香族分除去の試薬量及び測定}

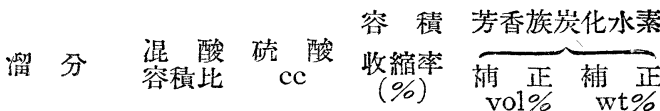

$\begin{array}{llllll}(4) & 3 & 15 & 165 & 156 & 189 \\ (6) & 3 & 15 & 234 & 226 & 265 \\ (7) & 3 & 10 & 144 & 135 & 15.9 \\ (8) & 3 & 15 & 236 & 228 & 262 \\ (9) & 3 & 15 & 272 & 255 & 30.1 \\ (10) & 3 & 15 & 311 & 304 & 341 \\ (11) & 45 & 25 & 417 & 407 & 448 \\ (12) & 4.5 & 25 & 432 & 42.3 & 464 \\ (13) & 3 & 15 & 379 & 373 & 417 \\ (15) & 45 & 25 & 421 & 411 & 451 \\ (16) & 45 & 25 & 462 & 453 & 492\end{array}$

（II） ナフテン系及びパラフィン系炭化水素の定量 カソリンのナフテン系及ひパラフィン系炭化水素の 定量に就いては Nenitzescu の方法に準拠して，脫芳 香族炭化水素 $5^{\circ}$ 分劃油の平均分子量及び平均比屈折 率を承めその成分含有率（nt％) を算出した。こらし て原カソリン分溜油及ひ芳香分除去カッリン分留油に ついて，夫々その留分に対する各成分の wt \% を承め た結果は第 6 表及ひ第 7 表に示す通りてある。

\section{第 6 表 原ガリン分溜油の飽和炭化水素成分}

$\begin{array}{cccc}\text { 溜 分 } & \text { 比属折 } & \begin{array}{c}\text { ナフテシ系 } \\ \text { wt\% }\end{array} & \begin{array}{c}\text { パラフイン系 } \\ \text { wt\% }\end{array} \\ (6) & 03414 & 2788 & 7212 \\ (7) & 03364 & 5672 & 4328 \\ (8) & 03366 & 5358 & 4642 \\ (9) & 03374 & 4809 & 5191 \\ (10) & 03356 & 5856 & 4144 \\ (11) & 03360 & 5868 & 4632 \\ (12) & 03378 & 4153 & 5847 \\ (15) & 03366 & 4844 & 5156 \\ (16) & 03357 & 4963 & 5037\end{array}$

（IV） 各溜分のパラコールに就いて

夜体と平衡にある同㿼度の蒸気の密度は，其夜体の 同盗度の比重DK対して無視せられるのて比パラコー 
第 7 表 芳香分除去ガソリン分㯰油の

\section{飽和炭化水素成分}

$\begin{array}{lccc}\text { 溜 分 } & \text { 比属折 } & \begin{array}{c}\text { ナテテ系 } \\ \text { wt\% }\end{array} & \begin{array}{c}\text { パフイン系 } \\ \text { wt\% }\end{array} \\ \text { (6) } & 0.3394 & 42.90 & 57.10 \\ \text { (7) } & 0.3420 & 2343 & 76.57 \\ (8) & 0.3390 & 39.44 & 60.56 \\ (9) & 03384 & 43.86 & 56.14 \\ (10) & 0.3384 & 4123 & 5877 \\ (11) & 0.3377 & 44.46 & 55.54 \\ (12) & 0.3377 & 4576 & 5424 \\ (13) & 0.3383 & 37.48 & 62.52 \\ (14) & 03381 & 39.12 & 60.88 \\ (15) & 0.3384 & 3416 & 6584 \\ (16) & 0.3385 & 27.26 & 7274\end{array}$

ルPの算式として $\mathrm{P}=\sigma^{\frac{1}{4}} / \mathrm{D}$ を用いた。茲に $\sigma$ は其溫 度に於ける液体の表面張力とする。こうして原ガンッ 二溜分，不飽和分除去ガソッン溜分，芳香族除去後の ガソリン溜分, 脫芳香族ガソリン分溜油について液杜 差の平均値より表面張力 (dyne/cm) を承め, 更に比 パラコールの值を算出した。これらの結果を一括して 示せは第 8 表の通りである。

\section{第 8 表 比パラコール測定}

\begin{tabular}{|c|c|c|c|c|}
\hline & 表 & 比パラコ & -ル測定 & \\
\hline & 溜分 & $\begin{array}{c}\text { 焲杜差 } \\
\mathrm{cm}\end{array}$ & $\begin{array}{l}\text { 表面張力 } \\
\text { dyne } / \mathrm{cm}\end{array}$ & $\begin{array}{l}\text { パラコ } \\
\text { ール }\end{array}$ \\
\hline & $(3)$ & 0.590 & 21.30 & 2.94 \\
\hline & (4) & 0.585 & 20.89 & 2.93 \\
\hline & (5) & 0.576 & 20.87 & 2.89 \\
\hline & (6) & 0.608 & 22.36 & 2.90 \\
\hline & $(7)$ & 0.610 & 22.10 & 2.90 \\
\hline & (8) & 0610 & 22.52 & 2.89 \\
\hline 飽 和 分 & (9) & 0599 & 2303 & 2.87 \\
\hline & $(10)$ & 0614 & 23.14 & 2.84 \\
\hline & (11) & 0640 & 24.70 & 2.83 \\
\hline & (12) & 0.630 & 2498 & 2.84 \\
\hline & (13) & 0.642 & 24.41 & 2.87 \\
\hline & (15) & 0649 & 25.04 & 2.85 \\
\hline & $(16)$ & 0656 & 2545 & 2.83 \\
\hline & $(8)$ & 0.600 & 2147 & 2.95 \\
\hline & (9) & 0.596 & 2193 & 2.97 \\
\hline & $(10)$ & 0.615 & 22.18 & 2.94 \\
\hline $\begin{array}{l}\text { 芳香 族 分 } \\
\text { 除去ガりシ }\end{array}$ & (11) & 0.625 & 22.71 & 2.94 \\
\hline & $(12)$ & 0.612 & 22.67 & 2.97 \\
\hline & (15) & 0.640 & 2329 & 2.96 \\
\hline & $(16)$ & 0.640 & 23.43 & 2.95 \\
\hline
\end{tabular}

照芳香族分油 $\left\{\begin{array}{llll}(8) & 0.609 & 22.34 & 2.99 \\ (9) & 0618 & 2274 & 3.00 \\ (10) & 0.617 & 22.02 & 2.97 \\ (11) & 0.613 & 2190 & 2.96 \\ (12) & 0.625 & 22.40 & 2.97 \\ (13) & 0.625 & 2241 & 2.97 \\ (14) & 0.635 & 22.79 & 2.98 \\ (15) & 0.635 & 2283 & 2.98 \\ (16) & 0635 & 2287 & 298\end{array}\right.$

（備考）原ガソリン溜分は不䭂和分除去ガソリン溜 分と大差かないのて省略する。

不飽和炭化水素の含有量か漌少な為, 关のパラコー 几は承め難いか芳香族炭化水素は相当多量に含有せら れて抢るのて，芳香族炭化水素のパラコールは次の様 な計算に依り承められる。今 $\mathrm{a}$ を不飽和炭化水素, $\mathrm{b}$ を芳香族炭化水素の vol\%， $\mathrm{P}_{1}$ を不飽和分除去ガソリ ン， $\mathrm{P}_{2}$ を芳香分除去ガソリン，y を芳香族炭化水素 の比パラコールとすれば,

$$
y=\left\{(100-a) P_{1}-(100-a-b) P\right\}_{2} / b
$$

第 9 表は上式に依つて各溜分の芳香族炭化水素の比 パラコールを決定しな結果である。

第 9 表 芳香族岩化水素の比パラコール算出

芳香族炭化水

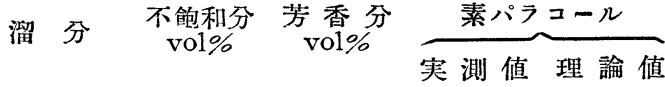

$\begin{array}{lllll}(8) & 0.12 & 22.84 & 2.69 & 2.67\end{array}$

$\begin{array}{lllll}\text { (9) } & 0 & 26.48 & 262 & 2.67\end{array}$

$\begin{array}{lllll}\text { (10) } & 0.20 & 30.37 & 2.62 & 267\end{array}$

$\begin{array}{lllll}\text { (11) } & 0.22 & 40.74 & 2.66 & 2.67\end{array}$

$\begin{array}{lllll}\text { (12) } & 0.31 & 4226 & 2.65 & 267\end{array}$

$\begin{array}{lllll}(15) & 0.44 & 41.09 & 2.68 & 2.68\end{array}$

$\begin{array}{lllll}\text { (16) } & 0.35 & 45.28 & 268 & 268\end{array}$

前表の不飽和分について說明を加之ると次の通りで ある。不飽和分を二重結合 1 箇を有するオレフィン系 炭化水素と見做して，その分子量はガッリン溜分の本 均分子量に等しいと仮定する。そ弓すれはォレフィン 系炭化水素の比重 $d_{0}$ を求められ，次に vol\% $=\mathrm{wt} \%$ $\times d$ (原溜分の比重) / $d_{0}$ によつて不飽和分の $\mathrm{wt} \%$ を vol\%、に換算したものてある。前表に於て芳香族炭化 水素の比パラコールに就いて測定値と理論値とを比較 すると良く一致している。茲に $90 \sim 115^{\circ} \mathrm{C}, 125 \sim 135$ ${ }^{\circ} \mathrm{C}$ 間の溜分に対与る芳香族炭化水素の比パラュー 几の理論値は夫々トルォール，キシロールに関する Landolt の表より導いた值てある。この様な一致は芳 香族炭化水素除去に関する改良硫硝酸法の正確な事の 
傍証とも言い得られる。

\section{(V) 緦}

括

1. 原カッリン中の不飽和分の 定量的除去には $80 \%$ 硫酸を用いた。一方臭素価法によつてその含有量を求 めたか僅少てある。

2. 芳香族炭化水素の定量的除去には硫确酸法を改良 した方法を用いた。此方法に拠る芳香放分の最大含有

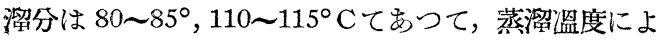

る比重, 属折率の変化の最大溜分と一致している。剆 ち此溜分はベンゾール，トルォールに当る。

3 Nenitzescu の方法に拠つてナフテン及ひパラフ イン炭化水素の定量を行つた。

4 不饱和分除去ガリリン，芳香族分除去ガリリン， 脫芳香族分油分溜ガリリンの备溜分のパラコールを求 め, 之上り芳香族炭化水素のパラコールを算出し, そ の理論値によく一致する事を認めた。

\section{第 3 報 ガリリンの構造分析論とその適用に就て}

\section{（I） ガソリンの構造分析論}

ガッリンの飽和炭化水素の構造分析——パラフィン 系炭化水素にあつてはその側鎖の平均数の決定，ナフ テン系炭化水素にあつてはその核を作る炭素原子の数 の決定一一をするに，Marder の各炭化水素系に対 する比パラコールと分子量の関係曲線を用いた。一方 パラフィン系炭化水素の正パラフィン系よりの偏差を 表す恒数としてはネクラッーの恒数がある。此恒数を パラフィン系炭化水素の異性体について算出した結果 を綜合して次の事項を知り得た。

1. 正パラフィン系炭化水素は炭素原子数の多少に拘 らす，一定値 33.27 を有し，パラフィン系炭化水素の分 枝数の增加に從い一定值との負の偏差の增加を來す。

2. 総てのパラフィン系炭化水素のネクラッー恒数は 全体を通じて，正パラフィン系炭化水素の值か最大て ありそれ以上の数值を示す事かない。

茲には以上の関係を饱和炭化水素混合夜の場合に応 用して，パラフィン炭化水素の分枝数を承めよらとす るものてある。今パラフィン炭化水素をその沸点によ つて $5^{\circ} \mathrm{C}$ 分劃区分に配置して, 各所属炭化水素の分 枝数に從つてネクランーの恒数の 33.27 よりの偏差 $\left(\Delta \mathrm{K}_{\mathrm{N}}\right.$ として表す) の値を承めれは,例之は90 95 ${ }^{\circ} \mathrm{C}$ 溜分に於ては分枝数 1 及び 2 の 種のパラフィン系炭 化水素よりなく， $\Delta \mathrm{K}_{\mathrm{N}}$ の值は夫々 0.71〜0.79, 0 95て 岁る。又 $120 \sim 125^{\circ} \mathrm{C}$ 溜分に於ては正及ひ分枝数 3 の 2 種のパラフィン采炭化水素よりなく,この場合の $\Delta \mathrm{K}_{\mathrm{N}}$ の值は夫々 $0 ， 225$ てある。即ち $\Delta \mathrm{K}_{\mathrm{N}}$ に関し てこの樣な一聯の関係を承める事が出來る。今炭素原 子数の同一なパラフィン系炭化水素の平均比属折を算 出してその分子量との関係曲線を画く時はその異性体 の比属折の相違は 0.0020 を越之ない。即ち备炭素原 子数のパラフィン系炭化水素の平均比属折と分子量と の関係を追跡すると，筑ね從來の相当曲線に似た曲線 を得る。こらして今該曲線上に与えられた分子量に相 当するパラフィン系炭化水素の比属折を求める時は,
その溜分中に実際含有せられているパラフィン柔炭化 水素の比屈折との差は 00020 以內てある。故に与之 られた分子量を有する溜分に於て分子量はその倛とし て, 唯比屈折たけ上記最大限の \pm 0.0020 の変化をす る時, 相応するネクラッーの恒数 $\mathrm{K}_{\mathrm{N}}$ の変化を算出す ると，その值は総じて約 015 と見る事か出來る。次 にパラフィン系炭化水素の分子量に若干の誤差を代 5 時，比属折にも誤差を生する。この样な場合 $\mathrm{KN}$ に幾 何の影響がるかを算出してみると分子量に \pm 2 の誤 差がある時, 落起される $\mathrm{K}_{\mathrm{N}}$ の誤差は約 \pm 0.35 てあ る。更に $\mathrm{K}_{\mathrm{N}}$ に於ける沸点の誤差を考えると $5^{\circ} \mathrm{C}$ 分 劃分溜であるから誤差の最大值は士2.5ㄷ Cてある。こ ろして $\mathrm{K}_{\mathrm{N}}$ に於ける誤差は約 0.20 てある。以上論じ た比屈折，分子量，沸点による $\mathrm{K}_{\mathrm{N}}$ の誤差の総計は分 子量測定に \pm 1 の誤差がるるのとすれは， $0.15+$ $0.18+0.20=0.53$ と見て差支えなく，士2 の誤差を認 めれは $0.15+0.35+0.20=0.70$ と見てよい。

巳て飽和炭水素の構造分析をするには，先つ予め知 られているパラフィン，ナフテン系炭化水素の $w t \%$ を炭化水素の比重 $d_{4}^{20}$ と分子量との関係図より vol\% に換算して置か水はなら奴。次にナフテン系炭化水素 をI (シクロペンタン系)，II（シクロへキッン系)， III(ンクロヘプタン系但し沸点又は分子是の関倸より その存在しない事か明らかなものは除く) と仮定して 次式によつて相応したパラフィン采炭化水素の比ハラ コール $\mathrm{P}_{\mathrm{P}}$ を算出する。

$$
\mathrm{P}_{\mathrm{P}}=\left(100 \mathrm{P}-\mathrm{V}_{\mathrm{N}} \mathrm{P}_{\mathrm{N}}\right) / \mathrm{V}_{\mathrm{P}}
$$

$\mathrm{P}_{\mathrm{N}}$ ：ナフテン炭化水素の比パラコール，P. 溜分の 実測パラコール， $\mathrm{V}_{\mathrm{N}}, \mathrm{P}_{\mathrm{P}}$ : ナフテン，パラフィン系 炭化水素の vol\%故に一溜分についてナフテン，パラ フィン系炭化水素の比パラコールの組合せは多くと必 3 個である。此の內パラフィン炭化水素の比パランー 几の算出値が，その範囲より遠さかる样な組合せは趸 却する。一方溜分附近の沸点を有するナフテン炭化水 素の I，II，II のものを選びその分子量を求める。 
ナ・フンン炭化水素はその系別に種類があるが，相当広 い沸点範囲に互つて多くは分子量の相等しい便益があ るので溜分の沸点よりナフテン炭化水素の分子量を決 定することか泏來る。がッリンの精溜は十分に行い得 る事が出來るので炭素一原子数を異にするナフテン系 炭化水素は普通混在する事かないか，その中間附近の 溜分にあつては炭素一原子を異にするナフテン系炭化 水素の何れを含む可能性があるこの場合にはナフ テン炭化水素の分子量を各々の值に仮定して， $\mathrm{K}_{\mathrm{N}}$ を 算出する。此の時此の值が 33.27 より設容される誤差 の範囲を越えて，大きいるのは，その仮定の誤謬なこ とを意味するものである。此の事はナフテン炭化水素 の分子量が炭素一原子数を巽にして何れであるか判別 する事が出來奴時ぞの解答を与えを手脚となる。次に ナフテン炭化水素の分子量に相灾したパラフィン炭化 水素の分子量 $\mathrm{P}$ を次式によつて求める。

$$
\mathrm{P}=\mathrm{N}+(\mathrm{W}-\mathrm{N}) 100 / \mathrm{P}
$$

$\mathrm{W}$ : 溜分の実測分子量

$\mathrm{N}$ : ナフテン炭化水素の分子量

$\mathrm{P}$ : 脫芳香族油溜分のパラフィン炭化水素の $\mathrm{wt} \%$

之から上記算出分子量に相応するパラフィン炭化水 素の比属折を求めて $\mathrm{K}_{\mathrm{N}}$ を算出する。こうして各溜分 の $\mathrm{K}_{\mathrm{N}}$ の算出值從つて 33.27 よりの差 $\Delta \mathrm{K}_{\mathrm{N}}$ の值が 得られ，これに 00.53 又は \pm 0.70 の誤差があるけ のと見て前述つ基準に拠つて，パラフィン炭化水素の 平均分子数を得る。 $\mathrm{K}_{\mathrm{N}}$ に若干の誤差があるので分枝 数は唯一種に限られる事なく，例えば 1 又は 2 の样に 決定せられるのを寧ろ普通とする。此 $\mathrm{K}_{\mathrm{N}}$ にるパラ フィン炭化水素の分枝数の決定と矛磨する事のない。 ラフィン, ナフテン炭化氷素の比パラコールの組合せ を選ぶと，その組合せこそは飽和炭化水素の構造分析 に解決を与えるものてある。以上の論旨に基いて或溜 分のパラフィン炭化水素の推定に於ては, その溜分の 沸点範囲內にあつて，所要の構造を有するものを選択 すべきである。こういら條件に適合するパラフィン炭 化水素のない溜分は隣接溜分のパラフィン炭化水素の 混在を意味する。

\section{（II） 実驗結果への適用}

さて実驗結果に基いて脫芳香分油溜分の構浩分析を 行万には，先つ各溜分の家測分子量，沸点より定めた ナフテン系炭化水素の分子量, パラフィン系炭化水素 の $\mathrm{wt} \%$ 上りパラフィン系炭化水素の分子量を算出与 る。次に此のパラフィン炭化水素の分子量に相応する $\mathrm{K}_{\mathrm{N}}$ を算出して 33.27 との差師ち $\Delta \mathrm{K}_{\mathrm{N}}$ を求める。此 れに $\pm 0.35 \sim 0.70$ の誤差を考慮に入れた值が各パラ
フィン系炭化水素について算出した分枝数と $\Delta \mathrm{K}_{\mathrm{N}}$ と の関係数值の範囲に入るかどらかによつてパラフィン 炭化水素の分枝数を定める。一方ナフテシ炭化水素を

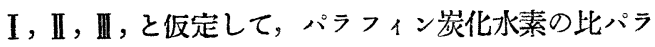
コールを算出して飽和炭化水素の比パラコール分子量 関係曲線に基いて，その分枝数を定める。両者の結果 を相照合すると各溜分の構造決定をなすことが出來 る。例之ば 90〜 95ㄷ 溜分はナフテン岸化水素は I, II の何れであつても $\Delta \mathrm{K}_{\mathrm{N}}$ 上り分枝数を求めれは I， パラコールの計算ては I，II 從つて分枝数は夫々 2 , 1でる。故にナフテン炭化水素はII，パラフィン炭 化水素は分枝 1 本のものである。95 100 $\mathrm{C}$ 溜分はナ フテン炭化水素は I， II の何れても $\Delta \mathrm{K}_{\mathrm{N}}$ より分枝 数を求めれは 0 , パラコールの計算ては， I, II に從 つて分枝数は夫々 $1 ， 0$ である。故にナフテン炭化水 素はII，パラフィン炭化水素はノルマルと決定せられ る。同様にして 105 $110^{\circ} \mathrm{C}$ はナフテン炭化水素は II，パラフィン炭化水素の分枝数 $2,115 \sim 120^{\circ} \mathrm{C}$ は II $, 1: 120 \sim 125^{\circ} \mathrm{C}$ は II, 0 と決定する。但し 130 $\sim 135^{\circ} \mathrm{C}$ は I 又はIII，I叉は 2 となり，一義的に決定 し得ない。又 100〜105, 110〜115, 125 130 ${ }^{\circ} \mathrm{C}$ は $\mathrm{KN}$ 上り分枝数を定め得ない。これは隣接溜分の成分の混 在を意味するものである。この样にして脫芳香族分油 の成分を推定すると， 90〜95 C はメ゙チルシクローキ サン，メチルーキサン，95〜100足はメチルシクロー キサン，ノルマループタン, $105 \sim 110^{\circ} \mathrm{C}$ はメチルシ クローキッン，ヂメチルーキッン，115 $120^{\circ} \mathrm{C}$ はチ メチルシクローキサン,メチループタン, $120 \sim 125^{\circ} \mathrm{C}$ はヂメチルシクローキ步ン，ノルマルオクタン,130〜 $135^{\circ} \mathrm{C}$ はヂメチルシクローキサン, ヂメチループタン を挙げる事が出來る。成分分布図 (省略)，の山に相当 する点は可成り純粹てあると考学られるのて，105〜 $110^{\circ} \mathrm{C}$ は 2.4 ヂメチルーキサン及びヂチルシクロー キッンの $55.54 \% ， 4446 \%$ の混合液と見做して，混 合液の $n_{\mathrm{D}}^{20}$ をその成分の $n_{\mathrm{D}}^{20}$ より算出すると 1.4079 , 実測 $n_{\mathrm{D}}^{20}$ は 1.4080 , 同样に $120 \sim 125^{\circ} \mathrm{C}$ は算出 $n_{\mathrm{D}}^{20}$ は 1.4100 , 実測 $n_{\mathrm{D}}^{20}$ は 1.4097 てあつてよく一致して いる。

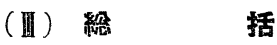

比パラコールとネクラッーの恒数とを併用するガン リンの構造分析論を䢞へ，次に此構浩分析論を錦水が ソリンに適用して，その各溜分の構造成分を推定した。 最後に以上の推定に基いて $105 \sim 110^{\circ} \mathrm{C}, 120 \sim 125^{\circ} \mathrm{C}$ の二溜分の屈折率 $n_{\mathrm{D}}^{20}$ の理論估を算出すると実測值と よく一致する結果を得た。 
交献

(1) M. Marder, ÖI u. Kohle, Erdöl u. Teer, 11, 1, 41, 1935, 150, 182, 222

(2) Nekrassow, Z. Physik. Chem. A., 140, 1929, 344
(3) Sugden, J. Chem. Soc., 119, 1921, 1438

(4) Nenitzescu, J. Inst. Pet.Tech., 25, 1939, 149

(5) M. Marder, ÖI u. Kohle, 11, 1935

(6) Nekrssaow, Z. Physik. Chem. A., 140, 1929 344

\title{
An Analytical Method of Gasoline Structure and Its Application on the Gasoline from Kinsui, Formosa (I, II, III)
}

\author{
By Kiyoji Togashi
}

(The Natural Gas Research Institute of the

Former Goverment-General of Formosa)

SYNOPSIS :-An analytical method of gasoline structure which used specific parachor and Nekrassows constant was related and its applicatıon to the gasoline from Kınsui, Formosa was reported.

\section{世界勤力会議へ日本の加入認めらる}

\section{一 1954 年, 南米に会合 —}

世界動力会議 1950 年度報告が，201 202, Grand Building, Trafalgal Sguare, W.C.2 中央事務局 より発行された。昨年 7 月のロンドン会議の議事錄及び 1950 年初め行われた国連経済社会理事会民間機構 委員会の勧告に関する問題が記載されている。

ての問題は今年初のニューデリーに於ける国際実行委員会に於ても注目された。

最近の英国国内委員会の年次会合に於て空席であつた名譽書記及び議長, 副議長, 名譽会計に A. Parkcr, V.de Ferrauti, H.Hobson, C.M.Croft の諾氏が選任された。

7 月パリの国際実行委員会は次回の世界動力会議部会を 1954 年 7〜8 月リオデヂャネイロに開催する梾 にとのブラヂル政府の支持の下に行われたブラヂル国內委員会の招待を満場一致で受理することに決定し た。世界動力会議が南米で開催されるのはこれが初めてであり，既にブラヂル国內委員会より提出された問 題が国際実行委員会に於て予備的に考察されたが，論議は熱帶及び亞熱帶の特殊な動力及び然料問題をめぐ つて焦中されるであら。

ての国際实行委員会に於てドィッ聯邦共和国及び日本の世界動力会議一の加入が許可された。てれ等両国 に於ては既に国内委員会が組織されている。(Gas J. 267, 1951，342）（編輯） 